\title{
Self-determination, emotions and exclusion in a blog of deaf people: a qualitative perspective
}

\author{
Autodeterminación, emociones y exclusión en un blog de personas sordas: mirada cualitativa \\ Autodeterminação, emoções e exclusão num blog de pessoas surdas: um olhar qualitativo
}

\author{
Ariana Castillo Alzuguren' \\ ORCID: 0000-0001-9754-6410 \\ María Cruz Sánchez-Gómez' \\ ORCID: 0000-0003-4726-7143
}

António Pedro Costa"

ORCID: 0000-0002-4644-5879

'Universidad de Salamanca. Salamanca, Spain. "Universidad de Aveiro. Aveiro, Portugal.

How to cite this article: Castillo Alzuguren A, Sánchez-Gómez MC, Costa AP. Self-determination, emotions and exclusion in a blog of deaf people: a qualitative perspective. Rev Bras Enferm. 2019;72(4):1094-101. doi: http://dx.doi.org/10.1590/0034-7167-2018-0573

Corresponding Author: Ariana Castillo Alzuguren E-mail: acal@usal.es

Submission: 08-03-2018

Approval: $03-06-2019$

\section{ABSTRACT}

Objective: to explore the deaf people's perceptions about their well-being, published on a weblog. Method: A free access spanish blog that's been created and used by deaf people is selected. Under qualitative methodology with a phenomenological approach, through the non-participating and asynchronous observation, sign language speeches are analyzed in 44 video messages uploaded by deaf bloggers. Results: in the speeches analyzed, inclusion's areas cited the most are self-determination, social inclusion and emotional well-being, these latter two in a negative way: social exclusion and emotional distress. Final considerations: The study participants state that the arrangements adopted for their inclusion are not enough, with feelings of discomfort prevailing in all areas and life stages. Solidarity initiatives, elimination of communication barriers and true transforming agents of our society are needed.

Descriptors: Deaf People; Inclusion; Self-Determination; Virtual Environment; Qualitative Research.

\section{RESUMEN}

Objetivo: explorar las percepciones de bienestar que las personas sordas vierten en un blog de Internet. Método: Se selecciona un blog español de acceso libre creado y utilizado por personas sordas. Bajo una metodología cualitativa con diseño fenomenológico, y a través de la observación no participante y asincrónica, se analizan los discursos en lengua de signos de 44 videomensajes publicados por blogueros sordos. Resultados: las áreas más mencionadas sobre su inclusión en los discursos analizados son la autodeterminación, el bienestar emocional y la inclusión social, estas dos últimas en sentido negativo: malestar emocional y exclusión social. Consideraciones finales: Los participantes del estudio manifiestan que los planes adoptados para su inclusión no son suficientes, y tienen sentimientos de malestar en todas las áreas y etapas vitales. Se hace necesario eliminar las barreras de comunicación y crear iniciativas solidarias con verdaderos agentes transformadores de la sociedad en la que vivimos.

Descriptores: Personas Sordas; Exclusión Social; Autodeterminación; Entorno Virtual; Investigación Cualitativa.

\section{RESUMO}

Objetivo: explorar as percepções dos surdos sobre seu bem-estar, publicados num blog. Método: foi selecionado um blog em espanhol de acesso gratuito criado e utilizado por pessoas surdas. Abordagem qualitativa assente na fenomenologia, através da observação assíncrona e não participante, os discursos realizados através de língua gestual são analisados em 44 vídeos que foram enviados por bloggers surdos. Resultados: nos discursos analisados, as áreas de inclusão mais citadas são autodeterminação, inclusão social e bem-estar emocional, sendo estas duas últimas de forma negativa: exclusão social e sofrimento emocional. Considerações finais: Os participantes do estudo afirmam que as alterações adotadas para a sua inclusão não são suficientes, com sentimentos de desconforto permanentes em todas as áreas e fases da vida. Iniciativas de solidariedade, eliminação de barreiras de comunicação e agentes transformadores reais da sociedade são necessários.

Descritores: Pessoas com Deficiência Auditiva; Inclusão; Autodeterminação; Ciberespaço; Pesquisa Qualitativa. 


\section{INTRODUCTION}

\section{Well-being of Deaf People and the Deaf Identity: From hearing loss to the deaf value}

Historically, the treatment of people with hearing disabilities from other members of society has been from a medical and physiological point of view, based on the need to rehabilitate the hearing and speech of deaf people, both from the Health and Educational fields. However, the oralist perspective has not achieved the inclusion and integral development of the deaf ${ }^{(1-2)}$. Auditory disabilities do not only involve hearing loss, but are multifaceted, affecting all of the vital areas of the individual: there are studies which report higher incidence of mental health problems in the deaf population, and in some cases there are significantly lower scores than in the hearing population with respect to both physical and psychological aspects of quality of life. There is also evidence that highlights the difficulties that deaf students have in the literacy process, given that the development of a child's neurolinguistic ability is not fostered by his or her natural language (sign language), besides that the educational system assesses the child through their second language (oral-written language) ${ }^{(2-4)}$. For decades Oliver Sacks has posited in his work that "It is not just language, but thought, that must be introduced. Otherwise the child will remain helplessly trapped in a concrete and perceptual world"(5). The presence of communication barriers cause isolation, prevent the development of a satisfactory existence, and can generate serious psychological problems: depression, anxiety, insomnia, stress, paranoid ideas and interpersonal sensitivity ${ }^{(6-7)}$. Inclusive approaches in the field of Education are essential, since, as explained by Echeita (2013), educational exclusion usually precedes social exclusion ${ }^{(8)}$. This exclusion is the reason why associations of the deaf have played such an important role for people with hearing disabilities. These associations are where deaf people can communicate, interact and develop their identities, and become the ideal space and environment for establishing a well-supported and cohesive Deaf community, which struggles to make visible the barriers they face in their daily lives ${ }^{(9-14)}$. Social and group identities are areas that have been widely studied: as human beings are inter-connected not only by chance but by their comparison to others, in search of characteristics that unite them and also make them different ${ }^{(15-16)}$. The development of a deaf identity begins with self-awareness and self-recognition, and is associated with high levels of self-esteem ${ }^{(17)}$. Ladd and Woll describe the development of the deaf identity as a process with two key phases that the deaf signer passes through: the first involves the deconstruction of the person as an individual with a hearing loss (it would be a deaf person, in lowercase); and the second is the reconstruction of the individual as a signer Deaf person (with capital letters) ${ }^{(18)}$.

In recent years, deaf people associations are being abandoned mainly by the younger generations, who are using social media more and more, since this overcomes the time-space limitations characteristic of communicating in sign language ${ }^{(9,14,19-20)}$. Social networks and blogs allow users to not only communicate through written messages, but videos can also be uploaded, providing Internet users with reading and writing problems the ideal means to express themselves through signed videos. Also, the signers are able to get their messages to reach more people and in more distant places ${ }^{(9,15,19,21)}$.

Deaf people associations serve as spaces of solace and support protected from the influence of the hearing and are, therefore, not easily accessible to people outside the deaf community. By contrast, the blogs and websites of deaf people are freely accessible to any Internet user. This provides an opportunity to not only know the benefits of the use of new technologies, but to have access to the deaf community in a less direct way. These tools also allow people to have access to what is being talked about such as the participants' concerns, needs and thoughts.

\section{OBJETIVE}

To explore the perceptions and experiences published in a blog by deaf people in sign language regarding their well-being in society. To this end, freely available, spontaneous and relevant multimedia documents published on the Internet are utilized ${ }^{(22)}$. This will allow us answering this question: how do deaf people feel about their quality of life and how do they share their experiences in the online environment? In addition, those transmitted exclusively in sign language are collected, since sign language is the preferred language of deaf people for communicating over written text, and permits us to analyze more elaborate, natural, extensive and rich discourses ${ }^{(19,22-25)}$.

\section{METHODS}

\section{Ethical aspects}

Content published in virtual spaces does not require prior informed consent on the part of users in order to include it in the study, because the material is public in nature. Hence, signed videos are a particularly interesting resource for carrying out these types of studies ${ }^{(26)}$. Nevertheless, the bloggers' identities remain anonymous because a code is assigned to each participant instead of using their real names.

\section{Theory and methodology references}

A case study is presented using a qualitative approach that seeks to obtain valid knowledge through a precise and meticulous description of the phenomenon in its context ${ }^{(23,27)}$. The qualitative method is characterized as being humanistic and naturalistic, and attempts to interpret the subjective manifestations that individuals make in their own environments, capturing the unique experiences that arise during their interactions with the world around them ${ }^{(25,28)}$.

\section{Type of study}

This is a phenomenological research, in which the aim are the experiences shared by a group of people about a concrete phenomenon, exploring all the information gathered until reaching the essence of the experience. In particular, it is an empirical phenomenological study, whose basis is to expose the personal stories of the protagonists, leaving out of the study the point of view that the researcher has towards this phenomenon ${ }^{(29)}$. 


\section{Methodological procedures}

The Figure 1 shows the phases that have been followed in this research process. A peripheral and asynchronous observation technique has been used: peripheral because the researcher maintains a passive role in the data collection, with the aim to minimize any possible interference concerning the participants; and asynchronous because of the particular characteristics of the sign language blog. This technique also allows us to collect videos that have previously been uploaded in order to carry out a posteriori analysis ${ }^{(22)}$. users spread across the Spanish geography, with the exception of Navarra and La Rioja. The Autonomous Communities most represented are Andalucía (41 profiles) and Cataluña (38 profiles).

The universe is composed of video posts, in this case "sign posts", uploaded to the selected blog. During 1 January 2016 to 30 April 2016 fifty-one video posts were obtained and reviewed based on a thematic approach. Specifically the content is referring to any aspect of the deaf community. This approach is recommended when the volume of data is vast, since identifying patterns helps to give meaning to a specific data set ${ }^{(30)}$.

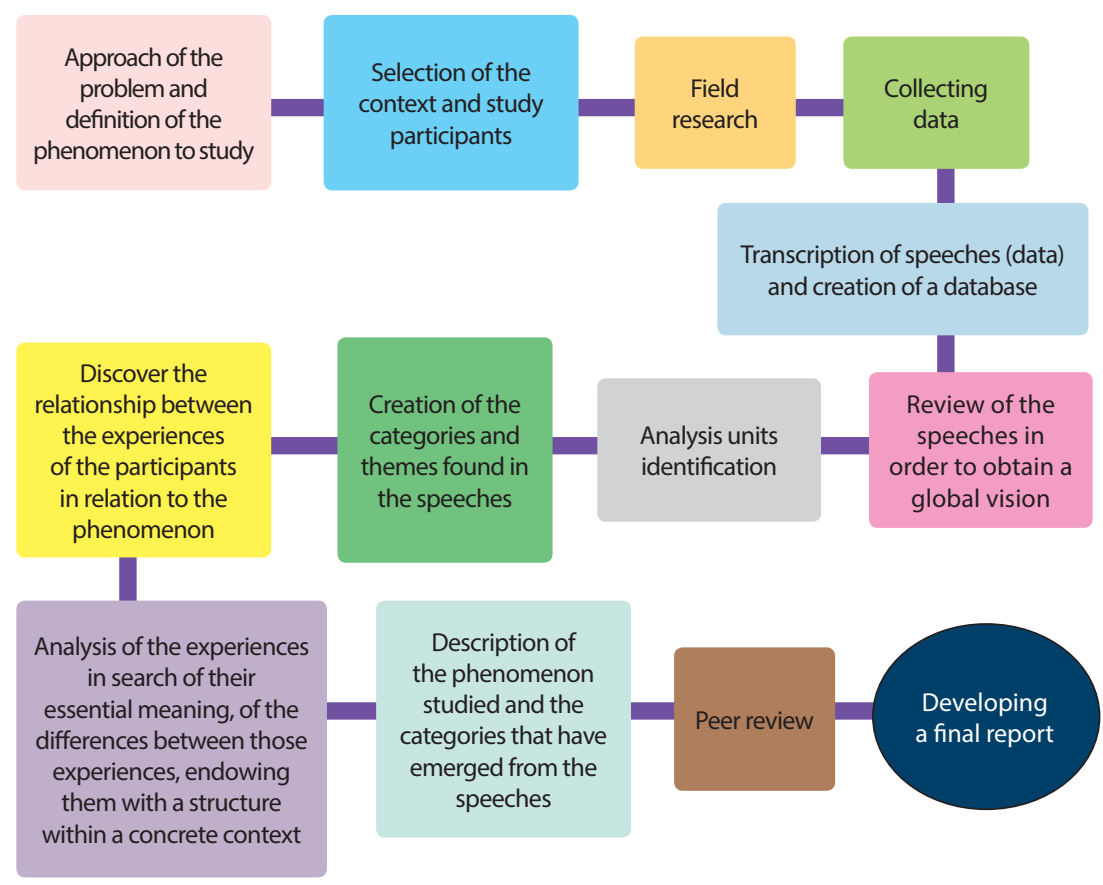

Figure 1 - Phenomenological study process ${ }^{(29)}$

\section{Study scenario}

The website www.signoblog.net was selected, after reviewing those sites potentially eligible for this study. This website is a free access community platform, which does not require registration in order to view its content, although it is necessary to create a user profile to publish videos and comments. It works by allowing bloggers to upload videos communicating in their sign language. Here the participants discuss the topics that interest them and the rest of users are able view these discussions and respond using either a signed video or written format. The preferred format is a signed video, because it discourses can be expressed in a more elaborate and natural way. The administrator of the site was contacted and informed us that the blog had been created in 2011 and that more than 10,235 signed posts (video posts) and 5,316 signed comments (response videos) had been uploaded since its creation. These uploads have been categorized into 34 different topics.

\section{Data source: Universe and participants}

There are 130 individual profiles of men (55\%), 87 individual profiles of women (37\%) and 19 group profiles (8\%). A total of 236

\section{Data gathering and organization}

After selecting fifty-one sign videos, it was determined that the unit of analysis was the word, that is, the minimum fraction with meaning ${ }^{(23)}$. In order to guarantee the methodological rigor, two types of inter-rater evaluation tests were carried: the first test, related to the interpretation of the signed videos, was undertaken by an active Spanish sign language interpreter with more than 15 years of experience and the administrator of the website who is deaf. Although both experts were contacted by email, we didn't receive any response, so we decided to eliminate seven video posts whose correct interpretation was doubtful, as some of the videos used a very pure Catalan Sign Language (LSC), which is different from Spanish Sign Language (LSE); other videos were exclude due to poor recording quality. In the second type of inter-rater test, experts in the field of Disability (teachers of the Master's degree in Disability Research and the Master's degree in Language and Communication Disorders of the University of Salamanca) were asked to validate the categories extracted from the discourse of the various sign posts. Based on the suggestions made by the experts and with the use of the NVIVO10 computer program, a conceptual map was constructed by integrating information units, metacategories, categories and subcategories that serve as the basis for the analysis of the content (see Figure 2).

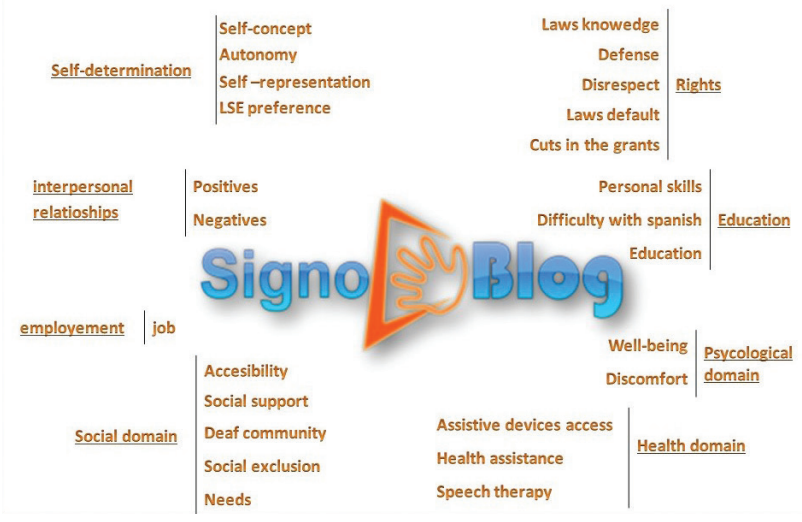

Figure $\mathbf{2}$ - Conceptual map 
In addition, the nature of the attitudes identified within the bloggers' discourses is differentiated and included in the conceptual map ${ }^{(31)}$. This classification system is widely used in numerous studies within social and educational contexts ${ }^{(32-34)}$ : according to this theory, attitudes are structured in three components: the affective component, the cognitive component and the behavioral component. The first one refers to feelings and moods towards something and/or someone. The second component refers to beliefs, opinions and knowledge about something and/or someone. And the third component refers to behaviors and behavioral tendencies regarding something and or someone.

\section{Data analysis}

Two types of analysis will be carried out: a semantic analysis by sweeping through the type of language used and the possible relationships between the words / signs, and a deeper content analysis, investigating the meanings and the communicative intention of these people, what they have lived through and how they have experienced it.

\section{RESULTS}

With the semantic analysis it's found that the most repeated words in the videos analyzed are represented in Figure 3. Two blocks of words can be seen, the first block, containing the most mentioned words related to people and the community, and the second block refers to communication.

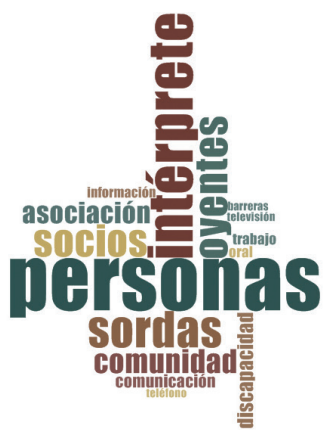

\begin{tabular}{|c|c|c|}
\hline \multicolumn{2}{|c|}{ DA Resultados de nube de palabra $\boldsymbol{x}$} & \multirow[b]{2}{*}{ Conteo } \\
\hline Palabra & Longitud & \\
\hline personas & 8 & 173 \\
\hline intérprete & 10 & 126 \\
\hline sordas & 6 & 101 \\
\hline oyentes & 7 & 93 \\
\hline socios & 6 & 89 \\
\hline comunidad & 9 & 66 \\
\hline asociación & 10 & 60 \\
\hline discapacidad & 12 & 44 \\
\hline comunicación & 12 & 36 \\
\hline oral & 4 & 31 \\
\hline trabajo & 7 & 31 \\
\hline información & 11 & 29 \\
\hline televisión & 10 & 25 \\
\hline teléfono & 8 & 25 \\
\hline barreras & 8 & 24 \\
\hline
\end{tabular}

Figure 3 - Representation of the most frequent words identified in the study

Figure 4 shows some results after analyzing the content of the sign videos: the number of coded references for each main dimension of the conceptual map. At first glance, we can already appreciate that three areas dominate the discourses: social, psychological and self-determination domains. It can also be seen that the social domain has the highest number of related comments. If the number of positive/well being and negative/discomfort comments is compared, depending on the communicative intention of the bloggers, the comments with negative/discomfort content predominate over those with positive/well being content.

\section{"The deaf are good too, we have a great visual capacity; sign language is a high quality and enormously rich language".}

Self-determination is one of the three domains that are mentioned most in the video posts, and has been found to be related to insult and suffering. The bloggers managed to develop a positive selfconcept regarding their deficiency, defining themselves as visual beings. In order to defend their rights, deaf communities and working together are considered important ${ }^{(9,20,35)}$; The Internet becomes a tool for the organization and mobilization of groups ${ }^{(14,19,21)}$, in such a way that the government and other institutions raise awareness of the communication barriers of deaf people:

\begin{abstract}
We need to meet in order to talk about and discuss problems such as the lack of access to universities, employment discrimination, cuts in the grants received by associations for funding different projects, ..., there is a need to sit down and talk publicly. Many people do it behind closed doors, secretly, and this way things will never improve (Excerpt taken from video 7 signed by blogger $F$ ).
\end{abstract}

Despite having legislative support, the rights of deaf people are violated ${ }^{(36-37)}$; what they most demand is accessibility through the figure of an interpreter, as well as the need to use LSE and the need to make citizens and institutions more aware:

Honestly for me, the interpreter is hugely important in my daily life for receiving information and for obtaining accessibility. Because if I go anywhere alone, it is very difficult for me to communicate, and I have to write, mime, make gestures, ..., a relative could also go with me and act as an interpreter, but I don't like this option, for me the figure of a professional sign language interpreter is much better. Having an interpreter helps me to communicate very fluidly and I can work autonomously (Excerpt taken from video 51 signed by blogger S).

"Normally people think I speak well, that I only have a hearing issue and that within society I can communicate, but it's not 


\section{like that, I prefer not to speak in these types of situations, it's hard for me to make myself understood, I have to try harder. I need an interpreter, that's the way it is".}

The social domain accounts for almost $50 \%$ of the content analyzed. Deaf people do not speak of social inclusion, but of social exclusion. They perceive discrimination and communication barriers. Negative/discomfort emotions were expressed in $75.7 \%$ of the cases, and the most frequent ones are feeling indignant, being offended and disappointed ${ }^{(4,6)}$. In the cases in which positive/well-being emotions are expressed, gratitude and curiosity are the most commonly mentioned. Also, the social domain is where the bloggers express more of their feelings in general.

Many references are made to the negative attitudes they perceive in society. Undoubtedly, behavioral component of attitudes is frequently mentioned, such as the fact that the requests for a sign language interpreter are often denied or that adaptations are usually of low quality, as in the case of subtitling ${ }^{(38)}$. This is understood as a negative attitude that discriminates against them.

Look, the 24-hour news channel has an interpreter because it's important and has a large audience, let's look at the other channels ... TVE1 channel doesn't have one, neither does Antena 3, only subtitles, and Cuatro channel has nothing, neither does Telecinco or La Sexta channel. Pfff ... Spanish National Television has a sign language interpreter because it's important, but they prefer to put them on the 24-hour news channel, and the rest of channels, Antena 3, Cuatro, Telecinco, they hide behind the fact that there is already an interpreter on the 24-hour news channel. Therefore, the hearing don't get used to; they zap through the channels and when they see the 24-hour news channel with an interpreter they quickly change it. The audience goes down because it's bothersome to watch television with an interpreter, it's like a distraction. The deaf are discriminated against. Okay maybe not an interpreter on all the channels, but it's like hey, take a look at the size of the interpreter box, please ... (Excerpt taken from video number 34 signed by blogger $\mathrm{G}$ ).

The inaccurate beliefs that people have about Deaf people make them feel very offended and generate discomfort, such as the use of the term illiterate and deaf-mute, terminology that is very far away from the concept these people have about themselves:

'Deaf'yes, but 'deaf-mute' is not the correct term; it's annoying for deaf people. Traditionally it was thought that the deaf person was unable to communicate with others. We can talk and shout, WE HAVE A VOICE (Excerpt taken from video number 13 signed by blogger $\mathrm{D}$ ).

\section{"... everything was in oral language, and I had a hard time trying to understand the teacher, I suffered, and my eyes hurt a lot. It was like a state of tension for me".}

They say they have suffered and felt disoriented throughout their education, because people with hearing impairment were treated in an exclusive way, being forced to speak and prohibited from the use of sign language. As a result, their education suffered ${ }^{(2-3,39)}$.

...after that they moved me to an integration school. In this school, there were a lot of hearing people, the teacher teached us orally, and I didn't understand anything, because at that time there were no interpreters, so I didn't get even a little bit, they read the book out loud but I didn't understand anything, uff it was so hard, I missed everything, and the rest of the mates suffered too. I repeated the grades once and another... (Excerpt taken from video number 5 signed by blogger $\mathrm{E}$ ).

\section{DISCUSSION}

The results of the present work are consistent with those reported previously in the literature. For Deaf people, social exclusion due to the lack of information isolation is of great concern. The communication barriers they face cause an imbalance that is both psychological and emotional and which generates feelings of resentment, offense and suffering in all stages of their lives ${ }^{(4,6)}$. The inaccessibility of information is a violation of their rights, and they express this with great unrest on the Internet. Through this weblog they offer mutual support, reinforce ties and encourage each other to defend their rights in an organized and united way ${ }^{(39)}$. The use of the Internet promotes a more extensive and robust community formed by people who identify with each other and struggle to be respected and included in society, a phenomenon that is also found in this study $(9,14,19-21,35)$.

One of the areas mentioned is Education. We have collected testimonies which state that under the oralist methodology, which was predominant at that time, they were unable to develop linguistic competences in the same way as their hearing classmates; not until they learned and used sign language were they able to develop literary skills ${ }^{(5)}$.

Complaints about the recognition of sign language and the Deaf community are not new, nor are they limited to the field of Education; although this field works as a thermometer to predict the degree of inclusion that society is willing to offer: various studies reveal that Deaf people share a story, an education, a feeling of likeness about having to face the same obstacles in their daily lives, same goals. However, above all, they share sign language, identifying themselves as a linguistic minority against the oral communities of their territories. The main claim of this group can be simple summarized in that LSE should be respected and that this language should have a place in society. To this end, any program implemented for the inclusion of people with hearing impairment should protect the right of these people to fully communicate in the language of their choice (Sign or Oral Language). This should include deaf students, as well as proposals for a bilingual curricula (sign language and Spanish), so that these children can successfully become literate throughout all educational stages.

In Spain there is a law (27/2007 of October 23) which recognizes Spanish and Catalan sign languages and regulates the means of support for oral communication of deaf people, hearing impaired and deafblind people. However more than ten years later, the regulation required to set this into action has not yet been drawn up. There are also other laws, such as the Royal Decree 1/2013 of November 29, which approves the consolidated text of the General Law on the rights of persons with disabilities and their social inclusion in the area of non-discrimination and universal accessibility. Despite this, there is still insufficient accessibility to media communication, where the presence of the figure of the interpreter remains limited and the subtitling can be inaccurate ${ }^{(38)}$. 


\section{Limitations of the study}

It is not possible to confirm a correlation between the testimonies and the perception of general well-being with their lives, since these discourses of deaf people refer to particular situations and particular experiences, mostly discomfort experiences. Although the choice of the website and the design of this research was done in such a way as to not alter the phenomenon and to capture it as natural and real as possible, it's not possible to analyze it deeply, which limited the scope of the conclusions.

\section{Implications/advancements in knowledge}

Using a qualitative approach within a weblog context, we immerse ourselves in a specific phenomenon based on the experiences of Deaf people in an attempt to understand the social and cultural processes they go through. Therefore, as future lines of research, a deeper analysis of each vital domain of Deaf people is necessary, using personal testimonies to determine if there is a relationship between the individual level and the general level of perceived well-being.

\section{Contributions to the fields of nursing and health care}

We have to work for inclusion of people with hearing impairment, and work for improving assistance to this group. The health has such a special meaning for them and so facing communication barriers in this area generates stress and anxiety. That is why establishing an action protocol for Deaf people's assistance would be very beneficial for both patients and health professionals. This protocol should include actions for environment physical adaptations (such as electronic advisements, lighted signs, etc.) and accredited sign language interpreters, so professional- patient are in full communication, getting a high quality assistance, as well as the professionals find easier treating with Deaf people.

\section{FINAL CONSIDERATIONS}

The objective of this study was to explore the perceptions and experiences that Dead people share in a sign language blog about their well-being in society. Using an open access blog allowed us to get to know how does these people feel about their well-being and how does they support each other, since they all pass through very similar situations. These bloggers express that the measures taken for their inclusion are not enough, declaring discomfort in all vital domains. It is necessary that political, health, educational and social institutions implement initiatives that promote solidarity, eliminate communication barriers and to live up to their role as truly transformers of the society in which we live. We hope that the results of this study will enhance the awareness of issues that impede the inclusion of people with disabilities.

\section{ACKNOWLEDGEMENTS}

We thank all of the deaf people who participated in this study, allowing us to use their video stories, and all of the professionals who dedicated their time and shared their knowledge so this work could be undertaken.

\section{REFERENCES}

1. Flaskerud JH. Culture, community, and diversity. Issues Ment Health Nurs [Internet]. 2014 [cited 2015 Oct 8];35(4):317-20. Available from: https://www.tandfonline.com/doi/full/10.3109/01612840.2013.835011

2. Nairouz Y, Boada AC. Consideraciones pedagógicas para el reconocimiento de la identidad personal y colectiva de las personas sordas. Rev Esp Discapac REDIS [Internet]. 2014 [cited 2018 Mar 11];2(2):255-60. [Available from: https://www.cedd.net/redis/index.php/redis/article/ view/87/pdf_25

3. Dammeyer J. Literacy skills among deaf and hard of hearing students and students with cochlear implants in bilingual/bicultural education. Deafness Educ Int[Internet]. 2014 [cited 2015 Nov 14];16(2):108-19. Available from: https://www.tandfonline.com/doi/abs/10.1179/1557069 $\mathrm{X} 13 \mathrm{Y} .0000000030$

4. Fellinger J, Holzinger D, Dobner U, Gerich J, Lehner R, Lenz G, et al. Mental distress and quality of life in a deaf population. Soc Psychiatry Psychiatr Epidemiol[Internet]. 2005 [cited 2016 Jun 20];40(9):737-42. Available from: https://www.ncbi.nlm.nih.gov/pubmed/16143834

5. Sacks O. Seeing voices: a journey into the world of the deaf. Berkeley: University of California Press. 1989.

6. Fellinger J, Holzinger D, Pollard R. Mental health of deaf people. Lancet [Internet]. 2012 [cited 2015 Dec 13];379(9820):1037-44. Available from: http://sasmhd.org.za/main/wp-content/uploads/2014/04/2012-Lancet-deafmh-review-comment-editorial.pdf

7. Reis RJDS, Machado MM, Gati HH, Falk JA. Dignity promoted or violated: how does the deaf person included perceive it? Rev Adm Mackenzie [Internet]. 2017 [cited 2013 Mar 13];18(3):178-202. Available from: http://www.scielo.br/pdf/ram/v18n3/1678-6971ram-18-03-0178.pdf

8. Echeita G. Inclusión y exclusión educativa. De nuevo «voz y quebranto». REICE Rev Iberoam Sobre Calid Efic Cambio En Educ [Internet]. 2013 [cited 2017 Oct 8];11(2). Available from: http://www.redalyc.org/resumen.oa?id=55127024005

9. Hamill AC, Stein CH. Culture and empowerment in the Deaf community: an analysis of Internet weblogs. J Community Appl Soc [Internet]. 2011 [cited 2015 Oct 8];21(5):388-406. Available from: https://onlinelibrary.wiley.com/doi/10.1002/casp.1081

10. Ladd $P$, Gulliver M, Batterbury S. Reassessing minority language empowerment from a Deaf perspective: the other 32 languages. Deaf Worlds [Internet]. 2003;19(2):6-32. Available from: https://www.researchgate.net/profile/Sarah_Batterbury/ 
publication/242379500_Reassessing_Minority_Language_Empowerment_from_a_Deaf_perspective_The_other_32_Languages/ links/0c96053bdb029953b3000000/Reassessing-Minority-Language-Empowerment-from-a-Deaf-perspective-The-other-32-Languages.pdf

11. Ortiz I de los RR. Comunicar a través del silencio: las posibilidades de la lengua de signos española. Universidad de Sevilla; 2005.312 p.

12. Rodríguez Martín D. El silencio como metáfora: una aproximación a la Comunidad Sorda y a su sentimiento identitario. Perifèria Rev Investig Form En Antropol. 2013 [cited 2015 Dec 13];18(1):23-50.

13. Senghas RJ, Monaghan L. Sign of their times: Deaf communities and the culture of language. Annu Rev Anthropol[Internet]. 2002 [cited 2015 Dec 22];31:69-97. Available from: http://sonify.psych.gatech.edu/ walkerb/classes/assisttech/pdf/senghas(2002).pdf

14. Valentine G, Skelton T. Changing spaces: the role of the internet in shaping Deaf geographies. Soc Cult Geog[Internet]. 2008 [cited 2016 Mar 15];9(5):469-85. Available from: https://www.tandfonline.com/doi/abs/10.1080/14649360802175691

15. Barak A, Boniel-Nissim M, Suler J. Fostering empowerment in online support groups. Comput Hum Behav [Internet]. 2008 [cited 2016 Jun 5];24(5):1867-1883. Available from: http://citeseerx.ist.psu.edu/viewdoc/download?doi=10.1.1.475.4579\&rep=rep1\&type=pdf

16. Molano OL. Identidad cultural un concepto que evoluciona. Opera. 2007;(7):69-84.

17. Bat-Chava Y. Diversity of deaf identities. Am Ann Deaf. 2000;145(5):420-8.

18. Woll B, Ladd P. Deaf communities. Oxf Handb Deaf Stud Lang Educ. 2003;151-63.

19. Power D, Power MR. Communication and culture: signing deaf people online in Europe. Technol Disabil [Internet]. 2009 [cited 2016 Jun 13];21(4):127. Available from: https://core.ac.uk/download/pdf/143858660.pdf

20. Shoham S, Heber M. Characteristics of a virtual community for individuals who are d/deaf and hard of hearing. Am Ann Deaf[Internet]. 2012 [cited 2016 Jan 27];157(3):251-63. Available from: https://www.ncbi.nlm.nih.gov/pubmed/22978201

21. Blom H, Marschark M, Vervloed MPJ, Knoors H. Finding friends online: online activities by deaf students and their well-being. Plos One [Internet]. 2014 [cited 2016 Mar 07];9(2):e88351. Available from: https://journals.plos.org/plosone/article?id=10.1371/journal.pone.0088351

22. López DMO, Gómez MCS. Técnicas de recolección de datos en entornos virtuales más usadas en la investigación cualitativa. Rev Investig Educ[Internet]. 2006 [cited 2016 May 11];24(1):205-22. Available from: https://revistas.um.es/rie/article/view/97661/93701

23. Anguera MT. Evaluación de programas desde la metodología cualitativa. Acción Psicológica [Internet] 2008 [cited 2016 Jun 5]. Available from: http://e-spacio.uned.es/fez/view/bibliuned:AccionPsicologica2008-2-0005

24. Carr D. Constructing disability in online worlds: conceptualising disability in online research. Lond Rev Educ[lnternet]. 2010 [cited 2016 Mar 12];8(1):51-61. Available from: https://www.ingentaconnect.com/content/ioep/clre/2010/00000008/00000001/art00006?crawler=true\&mi metype=application/pdf

25. Martínez J. Métodos de Investigación Cualitativa. Rev Investig Silogismo [Internet]. 2011 [cited 2016 May 12];1 (08). Available from: http:// www.cide.edu.co/ojs/index.php/silogismo/article/view/64

26. Crasborn $\mathrm{O}$. What does «informed consent» mean in the internet age? Publishing sign language corpora as open content. Sign Lang Stud [Internet]. 2010 [cited 2016 Jan 27];10(2):276-90. Available from: https://repository.ubn.ru.nl//bitstream/handle/2066/86297/86297. pdf?sequence $=1$

27. Vicario BP, Gómez MCS, García AG. Evaluar la calidad en la investigación cualitativa. Guías o checklists. En: Investigar la Comunicación hoy Revisión de políticas científicas y aportaciones metodológicas: Simposio Internacional sobre Política Científica en Comunicación [Internet]. Facultad de Ciencias Sociales, Juridicas y de la Comunicacion (UVa Segovia); 2013 [cited 2016 Jun 5]. p. 581-96. Available from: http:// dialnet.unirioja.es/servlet/articulo?codigo $=4229112$

28. Sarrado JJ, Clèries X, Ferrer M, Kronfly E. Evidencia científica en medicina:¿Única alternativa? Gac Sanit[Internet]. 2004 [cited 2016 May 12];18(3):235-44. Available from: http://scielo.isciii.es/pdf/gs/v18n3/revision2.pdf

29. Hernández Sampieri R, Fernández Collado C, Baptista Lucio P. Metodología de la investigación. Vol 3. México: McGraw Hill [Internet]. 2006 [cited $2018 \mathrm{Jul}$ 23]. Available from: https://s3.amazonaws.com/academia.edu.documents/38911499/Sampieri.pdf?AWSAcces sKeyld=AKIAIWOWYYGZ2Y53UL3A\&Expires=1547743488\&Signature=73tuzNE1DQae2ZdyP6zOV4NzGZQ\%3D\&response-contentdisposition=inline\%3B\%20filename\%3DSampieri.pdf

30. Miles MB, Huberman AM, Saldaña J. Qualitative data analysis: an expanded sourcebook. 3o ed. Thousand oaks: Sage[Internet]. 2013[cited 2017 Sep 28]. Available from: http://www.theculturelab.umd.edu/uploads/1/4/2/2/14225661/miles-huberman-saldana-designing-matrixand-network-displays.pdf

31. Triandis HC. Attitudes measurement and methodology. Attitudes Attitude Change. 1971 [cited 2016 Jun 20];26-59.

32. de Boer A, Pijl SJ, Minnaert A. Students' attitudes towards peers with disabilities: A review of the literature. Int J Disabil Dev Educ. 2012;59(4):379-92. Doi: https://doi.org/10.1080/1034912X.2012.723944

33. Díaz ALA, Rodríguez MÁA, Martínez BA. Cambio de actitudes hacia la discapacidad con escolares de Primaria. Psicothema [Internet]. 2008 [cited 2015 Dec 13];20(4):697-704. Available from: http://digibuo.uniovi.es/dspace/bitstream/10651/9480/1/Psicothema.2008.20.4.697-704.pdf

34. Vignes C, Godeau E, Sentenac M, Coley N, Navarro F, Grandjean H, et al. Determinants of students' attitudes towards peers with disabilities. Dev Med Child Neurol. [Internet]. 2009 [cited 2015 Dec 08];51(6):473-9. Available from: https://onlinelibrary.wiley.com/doi/ pdf/10.1111/j.1469-8749.2009.03283.x

35. Amichai-Hamburger Y, McKenna KYA, Tal S-A. E-empowerment: Empowerment by the Internet. Comput Hum Behav. [Internet]. 2008 
[cited 2016 Feb 21];24(5):1776-89. Available from: https://www.researchgate.net/profile/Tal_Samuel-Azran/publication/222367002_Eempowerment_Empowerment_by_the_Internet/links/59e9f8910f7e9bfdeb6cb4f5/E-empowerment-Empowerment-by-the-Internet.pdf

36. Gobierno de España G. LEY 27/2007, de 23 de octubre, por la que se reconocen las lenguas de signos españolas y se regulan los medios de apoyo a la comunicación oral de las personas sordas, con discapacidad auditiva y sordociegas [Internet]. 2007 [cited 2016 Jun 26]; Available from: http://judicatura.com/Legislacion/2401.pdf

37. Gobierno de España. Real Decreto Legislativo 1/2013, de 29 de noviembre, por el que se aprueba el Texto Refundido de la Ley General de derechos de las personas con discapacidad y de su inclusión social. Bol Of Estado. 2014.

38. Maciá MG. La accesibilidad al medio audiovisual para personas sordas: Estudio de caso de TVE. Miguel Hernández Commun J[Internet]. 2015 [cited 2016 Jun 24];(6):5-28. Available from: https://dialnet.unirioja.es/servlet/articulo?codigo=4962626

39. Murray JJ. Linguistic human rights discourse in deaf community activism. Sign Lang Stud[Internet]. 2015 [cited 2015 Dec 23];15(4):379-410. Available from: https://eric.ed.gov/?id=EJ1071545 